\title{
Persepsi Orang Tua Siswa tentang Pembelajaran Tatap Muka pada Era New Normal Pandemi Covid-19
}

\author{
Ahmad Fikri Sabiq \\ Institut Agama Islam Negeri (IAIN) Salatiga
}

\begin{abstract}
Keywords:
face-to-face learning,

Adaptation, New Normal
\end{abstract}

Kata Kunci:

Pembelajaran Tatap

Muka, Adaptasi, New

Normal

*Correspondence
Address:
ahmadfikrisabiq@gmail.c
om

\begin{abstract}
This study aims to determine the perceptions of parents toward the implementation of face-to-face learning during the new normal adaptation period. Online questionnaire, in the form of the google form, used as data collection method aimed at 406 parents of SD Plus Tahfizhul Quran (PTQ) Annida students. The results showed that the number of research respondents recorded to be 'agree' is $74.5 \%$, and those who are 'disagree' is $8.2 \%$, and doubt at the percentage of $17.3 \%$. The reason for agreeing is that to make the learning process to be more effective in which the online learning is considered to be not optimal, children are found to be bored, and the parents seems to be confused to make students become enthusiastic, the students are also behaving badly. Further, they state that they agree for school to have face-to-face learning as long as it is done by considering the health protocols. This is an adapting period for the students missed school and to be more conditioned. Meanwhile, the reason for disagreeing is that currently there are still Covid-19 cases found, students cannot comply with health protocols, and many educational clusters have emerged. The reason for expressing doubt is that when there are still cases, children cannot comply with health protocols, and parents do not understand the faceto-face learning systems.
\end{abstract}

\begin{abstract}
Abstrak: Penelitian ini bertujuan untuk mengetahui persepsi orang tua tentang pelaksanaan pembelajaran tatap muka pada masa adaptasi new normal. Pencarian data dalam penelitian ini menggunakan angket online dengan aplikasi google form yang ditujukan kepada seluruh orang tua siswa SD Plus Tahfizhul Quran (PTQ) Annida sejumlah 406 orang. Dari hasil penelitian diperoleh data yang menyatakan setuju $(74,5 \%)$, tidak setuju $(8,2 \%)$, dan raguragu $(17,3 \%)$. Alasan yang menyatakan setuju adalah agar pembelajaran lebih efektif, pembelajaran daring kurang maksimal, anak-anak sudah bosan, orang tua sudah bingung, agar siswa menjadi semangat, ketika di rumah anak menjadi kurang baik, dilaksanakan asalkan dengan protokol kesehatan, saat ini sudah waktunya adaptasi, anak sudah merindukan sekolah, anak menjadi lebih terkondisikan, dan berserah diri kepada Allah Swt. Alasan menyatakan tidak setuju adalah saat ini masih ada kasus, anak yang tidak bisa mentaati protokol kesehatan, dan bermunculan banyak klaster pendidikan. Alasan menyatakan ragu-ragu adalah saat masih ada kasus, anak-anak yang tidak bisa mentaati protokol kesehatan, dan orang tua belum faham sistem pembelajaran tatap muka.
\end{abstract}

\section{PENDAHULUAN}

Virus Corona atau Corona Virus Disease (Covid-19) telah memberikan dampak di berbagai bidang di tanah air, termasuknya bidang pendidikan. Sejak pertengahan bulan Maret 2020 lalu, dunia pendidikan melaksanakan kegiatan belajar mengajar secara jarak jauh, tanpa tatap muka di ruang kelas 
sebagaimana biasanya. Melalui Surat Edaran Nomor 4 Tahun 2020, Menteri Pendidikan secara tegas memberikan arahan berkaitan dengan hal ini.

Pembelajaran Jarak Jauh (PJJ) ini dilaksanakan sebagai upaya pendegahan penyebaran Covid-19 di bidang pendidikan dimana usia anakanak merupakan kelompok usia yang rentan terhadap penyakit. Salah satu penyebabnya adalah karena mereka belum bisa melakukan penjagaan diri terhadap lingkungan. Atas dasar menjaga anak-anak ini, pendidikan dilaksanakan secara daring yang dipandu oleh guru melalui sarana online.

Tidak bisa dipungkiri bahwa Pembelajaran Jarak Jauh (PJJ) ini memiliki banyak kendala, baik yang dialami oleh guru, siswa, ataupun orang tua yang mendampingi siswa untuk belajar di rumah. Dalam sebuah penelitian yang pernah penulis lakukan, ada $40 \%$ orang tua mengaku kesulitan dalam menkondisikan anak-anaknya untuk belajar di rumah.

Selanjutnya ada $30 \%$ orang tua terkendala waktu untuk mendampingi anaknya belajar. Dari mereka ada yang yang sibuk bekerja dan ada juga yang tidak bisa membagi waktu karena semua anaknya ada tugas belajar di rumah. Kendala selanjutnya adalah ada $17 \%$ orang tua yang kesulitan dalam memahami materi pelajaran dan kesulitan dalam memberikan penjelasan materi kepada anaknya. Selain tiga macam kendala di atas,

\footnotetext{
${ }^{1}$ Ahmad Fikri Sabiq, "Persepsi Orang Tua Siswa Tentang Kegiatan Belajar Di Rumah Sebagai Dampak Penyebaran Covid 19," Civic-Culture: Jurnal Ilmu Pendidikan PKn Dan Sosial Budaya 4, no. 1 (2020): 06.

2 In Setyorini, "Pandemi COVID-19 Dan Online Learning: Apakah Berpengaruh Terhadap Proses Pembelajaran Pada Kurikulum 13?,"
}

beberapa kendala lainnya adalah karena ada lingkungan yang kurang mendukung, sumber daya yang kurang mendukung, dan ada orang tua yang kurang sabar dalam mendampingi anakanaknya. ${ }^{1}$

Dalam penelitian lain yang dilakukan oleh Setyorini, disebutkan ada beberapa problematika yang dialami oleh peserta didik, guru, serta orang tua dalam kegiatan pembelajaran jarak jauh ini, yaitu penguasaan teknologi masih kurang, adanya penambahan biaya kuota internet, adanya pekerjan tambahan untuk orang tua dalam mendampingi anak-anaknya belajar, komunikasi dan sosialisasi antar siswa yang menurun, guru dan orang tua menjadi berkurang interaksinya dan jam kerja yang menjadi tidak terbatas bagi guru. ${ }^{2}$

Meskipun mengalami banyak kendala, namun kegiatan pembelajaran tidak boleh berhenti karena sekolah harus berorientasi pada global relevant need atau kebutuhan global yang relevan. ${ }^{3}$ Olah karenanya, diperlukan guru yang handal, strategi yang tepat, dan kerja sama kuat antara sekolah dan orang tua untuk menjawab tantangan pendidikan di tengah pandemi Covid-19 ini.

Selain berkenaan dengan problematika teknis di lapangan, pembelajaran daring juga menyisakan problematika di tingkat kebijakan. Meskipun saat ini Indonesia menempari peringkat ke-8 dalam pertumbuhan pemanfaatan pembelajaran secara

Journal of Industrial Engineering \& Management Research 1, no. 1 (July 5, 2020): 99, https://doi.org/10.7777/ jiemar.v1i1.31.

3 Syamsul Bahri and Novira Arafah, "Analisis Manajemen SDM Dalam Mengembangkan Strategi Pembelajaran Di Era New Normal," Tafkir: Interdisciplinary Journal of Islamic Education 1, no. 1 (August 11, 2020): 34. 
daring di tingkat global, namun masih terdapat hal yang harus diperbaiki terutama soal infrastruktur dalam penyediaan acces point di daerah terluar, terdepan, dan daerah terisolir. ${ }^{4}$

Saat ini, pemerintah sudah mulai mencanangkan era new normal, dimana ini merupakan era ketidakpastian, baik dalam kondisi sosial, ekonomi, kesehatan, dan termasuknya juga di bidang pendidikan. ${ }^{5}$ Era new normal ini merupakan langkah yang diambil oleh pemerintah dengan tetap memperhatikan resiko yang muncull sebagai dampak dari kebijakan ini.

Berkenaan dengan dunia pendidikan, saat ini sudah ada beberapa daerah yang melakukan uji coba pelaksanaan sekolah secara tatap muka. Bahkan sudah ada beberapa sekolah yang juga sudah melakukan pembelajaran sebagaimana biasanya namun tetap dengan protokol kesehatan. Langkah ini diambil sebagai upaya adaptasi masyarakat di tengah pandemi yang disebabkan Covid-19 ini.

Pelaksanaan pembelajaran tatap muka mendapat respon beragam dari para orang tua siswa. Ada yang setuju dan ada yang tidak. Apalagi banyak diberitakan di media tentang munculnya klaster pendidikan. Selain itu, semakin bertambahnya kasus yang terkonfirmasi positif terpapar Covid-19 semakin membuat masyarakat berpikir kembali untuk mengijinkan putraputrinya melaksanakan pembelajaran tatap muka di sekolah.

Dari dua arah pertimbangan di atas, rencana pelaksanaan pembela-

4 Roman Andrianto Pangondian, Paulus Insap Santosa, and Eko Nugroho, "Faktor - Faktor Yang Mempengaruhi Kesuksesan Pembelajaran Daring Dalam Revolusi Industri 4.0," Seminar Nasional Teknologi Komputer \& Sains (SAINTEKS) 1, no. 1 (February 21, 2019): 59, jaran tatap muka di tengah pandemi ini dilematis. Di satu sisi orang tua berharap anaknya bisa berangkat sekolah karena ada banyak masalah atau kendala dalam pembelajaran online, guru juga ingin mengajar peserta didiknya secara langsung agar bisa maksimal, dan anak-anak sudah mulai jenuh belajar dari rumah. Namun, di satu sisi Covid-19 ini masih menghantui para orang tua karena khawatir akan kesehatan anak-anaknya.

Dalam penelitian ini, penulis ingin mengkaji bagaimana tanggapan orang tua siswa tentang rencana pelaksanaan pembelajaran tatap muka di sekolah. Meskipun belum ada instruksi khusus yang berlaku secara umum untuk dilaksanakan pembelajaran tatap muka, namun saat ini sekolah-sekolah diharapkan untuk mempersiapkan diri. Penelitian ini menjadi penting karena diharapkan bisa menjadi bagian dari sumber pengambilan kebijakan bagi pihak terkait, baik oleh pemerintah, tim gugus tugas, dinas pendidikan, sekolah, dan orang tua serta masyarakat secara umum.

\section{METODE PENELITIAN}

Metode penulisan laporan penelitian ini menggunakan metode hybrid atau lebih dikenal mixed methode yang merupakan gabungan antara metode kuantitatif dan kualitatif. Menurut John W Creswell mixed method merupakan metode penelitian yang menggabungkan bentuk kualitatif dan kuantitatif. Metode ini melibatkan asumsi filosofis, penerapan metode

https://www.prosiding.seminarid.com/index.php/sainteks/article/view/ 122 5 Muhammad Qur'anul Kariem, "KONSEPSI KEBIJAKAN PEMERINTAH DI ERA NEW NORMAL," TheJournalish: Social and Government 1, no. 2 (June 26, 2020), 79. 
kualitatif dan kuantitatif, serta perpaduan dua metode dalam suatu penelitian. ${ }^{6}$ Metode ini termasuk tradisi baru yang diterapkan dalam beberapa dekade terakhir dan penggunaannya secara wajar dalam rangka memenuhi kebutuhan akan pemenuhan kekurangan masing-masing kuantitaif ataupun kualitatif.

Mixed method dalam penelitian ini menggunakan strategi triangulasi parallel (kunkuren), yaitu melakukan pengumpulan data kuantitatif dan kualitatif satu tahap dalam satu waktu. Bobot antara data kuantitatif dan kualitatif diatur secara seimbang, dengan kata lain pada saat membandingkan hasil data pada bagian pembahasan, terjadi perpaduan kedua jenis data tersebut (mixing data).

Menurut Lexy J. Moleong, metode kualitatif merupakan studi yang bertujuan untuk memahami fenomena yang dialami oleh subjek penelitian, seperti perilaku, persepsi, motivasi, dan Tindakan dan lainnya. ${ }^{7}$ Oleh karena itu, wawancara dengan orang tua tentang pembelajaran tatap muka di era new normal pandemi Covid-19 memberikan data kualitatif.

Selanjutnya, mengenai populasi penelitian, Suharsimi Arikunto menjelaskan bahwa populasi merupakan keseluruhan subjek yang akan diteliti. ${ }^{8}$ Secara lebih spesifik Sugiyono berpendapat bahwa populasi adalah wilayah generalisasi yang terdiri atas objek/subjek yang mempunyai kualitas dan karakteristik tertentu yang ditetapkan oleh peneliti untuk

6 Creswell, J. W. Research Design: Qualitative Quantitative and Mixed Methods Approaches. (Thousand Oaks: SAGE Publications, Inc, 2014)

${ }^{7}$ Moleong, L. J. Metodologi Penelitian Kualitatif. (Bandung: Remaja Rosdakarya, 2007) dipelajari, didisukusikan untuk kemudian ditarik kesimpulannya. ${ }^{9}$ Populasi penelitian ini adalah seluruh wali murid di SD Plus Tahfizhul Quran (PTQ) Annida Salatiga berjumlah 406 orang dengan rincian sebagai berikut:

Tabel 1 Sebaran Populasi

\begin{tabular}{ccc}
\hline No & Kelas & Jumlah \\
\hline 1 & I & 103 \\
2 & II & 77 \\
3 & III & 68 \\
4 & IV & 68 \\
5 & V & 49 \\
6 & VI & 41 \\
\hline \multicolumn{3}{c}{ Jumlah } \\
\hline
\end{tabular}

Sedangkan sampel menurut Sugiyono merupakan bagian dari jumlah dan karakteristik populasi. Namun penentuan sampel dalam penulisan penelitian ini adalah seluruh anggota populasi dijadikan sampel. Hal itu dilakukan karena jumlah penduduk yang relatif sedikit. Menurut Sugiono, sampling jenuh merupakan teknik pengambilan sampel yang semua anggota populasi dijadikan sampel. ${ }^{10}$

Adapun teknik pengumpulan data dalam penelitian ini adalah menggunakan angket dan wawancara. Instrumen angket dibuat berdasarkan pengembangan teori. Angket tersebut kemudian disusun ke dalam media angket online yaitu google form dan dibagikan kepada responden. Dalam satu waktu dilakukan juga wawancara terhadap responden. Wawancara yang

8 Arikunto, S., Prosedur Penelitian Suatu pendekatan Praktek. (Jakarta: Rineka Cipta, 2010), 173.

9 Sugiyono, Metode Penelitian Kuantitatif, Kualitatif dan R \& D. (Bandung: Alfabeta, 2012), 80.

${ }^{10}$ Sugiyono, Metode, 57-62. 


\begin{abstract}
dilakukan adalah wawancara terstruktur. Menurut Sugiyono wawancara terstruktur digunakan sebagai teknik pengumpulan data, bila peneliti telah mengetahui dengan pasti tentang informasi apa yang akan diperoleh. ${ }^{11}$ Wawancara pada penelitian ini dilakukan kepada populasi yang dalam pengisian angket memiliki peluang untuk ditindaklanjuti dengan wawancara. Jumlah sampel yang diwawancara sejumlah 6 orang yang mewakili setiap jenjang kelas.
\end{abstract}

Selanjutnya, berkenaan dengan analisis data, menurut Sugiyono adalah upaya menerjemahkan secara sistematis dari hasil pengumpulan data untuk meningkatkan pemahaman terhadap obyek yang sedang diteliti. ${ }^{12}$ Data dalam penelitian ini adalah campuran data kuantitatif dan data kualitatif. Data kuantitatif pada penelitian ini dianalisa menggunakan analisis deskriptif dengan rumus persentase, yaitu: Jumlah skor perolehan dibagi jumlah skor maksimal dikalikan $100 \%$. Data kualitatif hasil wawancara dikumpulkan kemudian dianalisis. Selanjutnya dari hasil kedua data kualitatif dan kuantitatif dikomparasikan untuk dicari titik persamaan kesimpulannya.

Tempat penelitian ini adalah di SD Plus Tahfizhul Quran (PTQ) Annida Salatiga yang beralamat di Jalan Jenderal Sudirman Nomor 239, Ledok, Argomulyo, Kota Salatiga. Adapun waktu pelaksanaan penelitian ini adalah

\footnotetext{
${ }^{11}$ Sugiyono, Metode, 233.

12 Sugiyono, Metode, 104.

13 Drever, J., Kamus Psikologi (The Penguin Dictionary of Psychology), N. Simanjuntak, Ed. (Jakarta: PT. Bina Aksara, 1988), 338.

${ }_{14}$ Ivancevich, J. M., Konopaske, R., \& Matteson, M.

T., Perilaku dan Manajemen Organisasi (Organizational Behavior and Management,
}

pada bulan Agustus sampai dengan September 2020.

\section{HASIL DAN PEMBAHASAN}

Secara etimologis, persepsi berasal dari kata berbahasa Inggris perception dan dari kata Latin percipare yang diartikan sebagai menerima atau mengambil. Dalam Kamus Psikologi, persepsi diartikan sebagai proses untuk mengingat atau mengidentifikasikan sesuatu. ${ }^{13}$ John M. Ivancevich menjelaskan persepsi sebagai proses kognitif dimana seorang individu memilih, mengorganisasikan, dan memberi arti kepada stimulus lingkungan. ${ }^{14}$ Oleh karenanya, dapat dikatakan bahwa objek dari persepsi adalah kondisi lingkungan dimana seseorang berada.

Melalui persepsi, seseorang berusaha merasionalisasi lingkungan dan objek, orang, dan peristiwa di dalamnya. Robert Kreitner dan Angelo Kinicki mengungkapkan bahwa persepsi merupakan proses kognitif yang memungkinkan kita untuk menjelaskan, memaknai dan memahami lingkungan sekitar kita.. ${ }^{15}$ Sedangkan Fred Luthans dalam bukunya Perilaku Organisasi Edisi Sepuluh, menyebutkan bahwa persepsi merupakan proses kognitif kompleks yang menghasilkan gambaran dunia yang unik, yang mungkin agak berbeda dari realita. ${ }^{16}$ Sedangkan pada bagian lain, dijelaskan bahwa proses persepsi atau filter dapat

Seventh Edition). (G. Gania, Ed.) (Jakarta: Erlangga, 2006), 116.

15 Kreitner, R., \& Kinicki, A., Perilaku Organisasi (Organizational Behavior). (E. Suandy, Ed.) (Jakarta: PT. Salemba Empat, 2003), 208.

${ }^{16}$ Luthan, F., Perilaku Organisasi (Organizational Behavior 10th Edition). (A. V. Yuono, S. Purwanti, T. Arie P, \& R. Winong, Eds.) (Yogyakarta: Penerbit Andi, 2006), 194-197. 
didefinisikan sebagai interaksi seleksi, organisasi, dan interpretasi yang rumit.

Persepsi ini sangat tergantung pada indera untuk data mentah, dan proses kognitif menyaring, memodifikasi, atau sepenuhnya mengubah data tersebut. Oleh karenanya, dalam menafsirkan suatu informasi atau peristiwa, setiap orang sangat mungkin memiliki persepsi yang berbeda dengan orang lain karena ada keterbatasan indera dalam proses menangkap informasi tersebut.

Selanjutnya, mengenai kegiatan belajar mengajar di masa new normal pandemi Covid-19 ini, pemerintah sudah mulai mempersiapkan langkah. Termasuknya adalah menyiapkan protokol kesehatan oleh masing-masing satuan pendidikan. Berdasarkan arahan dari pemerintah, protokol kesehatan yang wajib dimiliki oleh masing-masing satuan pendidikan adalah kelengkapan alat cuci tangan, kebersihan kamar mandi, fasilitas UKS, penyemprot hand sanitizer, area wajib masker, tersedianya faceshield, serta menjaga jarak aman antara satu dengan yang lain.

Beragam respon disampaikan oleh orang tua mengenai kegiatan belajar mengajar secara tatap muka ini. Berdasarkan dari hasil data yang diisi oleh orang tua siswa terkait pendapat mereka tentang setuju atau tidaknya pembelajaran dilaksanakan secara tatap muka. Dari data yang diperoleh, terdapat tiga pilihan jawaban, yaitu setuju, tidak setuju, dan ragu-ragu sebagaimana disajikan dalam tabel berikut:

Tabel 2 Penyataan Orang Tua

\begin{tabular}{lll}
\hline No & Pernyataan & Persentase \\
\hline 1 & Setuju & $74,5 \%$ \\
2 & Tidak Setuju & $8,2 \%$
\end{tabular}

\begin{tabular}{|c|c|}
\hline Ragu-ragu & $17,3 \%$ \\
\hline Jumlah & $100 \%$ \\
\hline
\end{tabular}

Dari tabel di atas, diketahui ada $74,5 \%$ orang tua menyatakan setuju kalau pembelajaran dilaksanakan secara tatap muka. Selanjutnya ada 8,2 $\%$ orang tua menyatakan tidak setuju sedangkan sisanya menyatakan raguragu.

Dari data tersebut, diketahui bahwa mayoritas orang tua menyatakan setuju untuk dilaksanakan pembelajaran tatap muka. Meskipun demikian, pendapat orang tua siswa yang menyatakan tidak setuju juga harus tetap dihargai sebagai bahan pertimbangan untuk membuat suatu kebijakan.

Selanjutnya, selain menyatakan setuju dan tidak setuju, orang tua siswa juga menyampaikan alasan atas pendapatnya tersebut. Bagi orang tua yang menyatakan setuju untuk dilaksanakan pembelajaran tatap muka, ada sebelas alasan yang menjadi dasar argumennya sebagaimana dalam tabel berikut:

Tabel 3 Alasan Menyatakan Setuju

\begin{tabular}{llc}
\hline No & \multicolumn{1}{c}{ Alasan-alasan } & $\%$ \\
\hline 1 & $\begin{array}{l}\text { Pembelajaran lebih } \\
\text { efektif }\end{array}$ & $41,6 \%$ \\
2 & Daring kurang maksimal & $12,2 \%$ \\
3 & Anak sudah bosan & $11,0 \%$ \\
4 & Orang tua bingung & $7,8 \%$ \\
5 & Siswa menjadi semangat & $7,3 \%$ \\
6 & Di rumah menjadi kurang & $6,1 \%$ \\
& baik & Asalkan dengan protokol \\
8 & Sudah waktunya adaptasi & $3,7 \%$ \\
9 & Anak rindu sekolah & $3,3 \%$ \\
\hline
\end{tabular}




\begin{tabular}{|c|c|}
\hline 10 Anak lebih terkondisikan & $0,8 \%$ \\
\hline $\begin{array}{l}11 \text { Berserah diri kepada } \\
\text { Allah }\end{array}$ & $0,4 \%$ \\
\hline Jumlah & $100 \%$ \\
\hline
\end{tabular}

Dari tabel tersebut, diketahui
bahwa alasan utama orang tua
menyatakan setuju dilaksanakan
pembelajaran tatap muka adalah agar
pembelajaran yang diikuti oleh siswa
menjadi lebih efektif dan maksimal
dengan persentasi sebanyak 41,6 \%.
Alasan ini relevan karena selama
pandemi covid ini, pembelajaran yang
dilaksanakan secara daring tidak
maksimal. Alasan mengenai
pelaksanaan pembelajaran daring
kurang maksimal ini menempati urutan
kedua dari alasan-alasan yang
disampaikan oleh orang tua siswa
dengan persentase sebanyak 12,2 \%.
Mereka berharap agar anaknya bisa
belajar secara maksimal yaitu secara
tatap muka.

Selanjutnya, ada sebanyak $11 \%$ orang tua siswa menyatakan bahwa anaknya sudah bosan dan jenuh selama pembelajaran di rumah ini. Terhitung ada sekitar lima bulan mereka tidak bertemu dan bercanda tawa bersama guru dan teman-temannya di sekolah. Ditambah dengan berbagai tugas menumpuk dari sekolah yang hanya disampaikan melalui alat komunikasi di gadget masing-masing. Keadaan diperparah dengan kurang sabarnya orang tua siswa dalam mendampingi anaknya belajar. Ada banyak orang tua yang bingung bahkan stres menghadapi anaknya yang susah untuk diajak belajar. Alasan kebingungan orang tua dalam mendampingi belajar ini menempati urutan keempat dengan persentase sebanyak 7,8 \%. Orang tua menjadi semakin bingung karena mereka sudah bekerja seharian ditambah harus mendampingi anaknya belajar. Apalagi banyak dari orang tua yang tidak memahami materi pelajaran yang harus dipahami oleh anaknya.

Selanjutnya, ada $7,3 \%$ orang tua siswa yang memberikan alasan setuju dengan pembelajaran tatap muka dengan harapan agar anaknya bisa menjadi semangat belajar. Alasan ini muncul dikarenakan selama belajar daring ini, semangat anak-anak tentunya menurun, tidak seperti sebelumnya saat masih dalam kondisi normal sebagaimana biasanya.

Di tengah kondisi kurang semangat belajar ini, para siswa butuh motivasi dari orang tua dan guru. Oleh karenanya, sebagai sarana alternatif solusi berkaitan dengan hal ini, di SD Plus Tahfizhul Quran (PTQ) Annida dilaksanakan kegiatan kunjungan ke rumah siswa (home visit) yang dilakukan oleh guru kelas. Kunjungan ini dilaksanakan dengan tujuan untuk memberikan semangat kepada siswasiswa tertentu yang mengalami kendala dalam pembelajaran daring dan siswa yang kurang semangat.

Selanjutnya, ada $6,1 \%$ orang tua memberikan alasan setuju untuk dilaksanakan pembelajaran tatap muka dikarenakan kalau di rumah dan di lingkungan sekitar rumah, anaknya menjadi kurang baik. Kondisi kurang baik ini bisa dari aspek pergaulannya, aktivitas kesehariannya, dan lain sebagainya. Dari kondisi tersebut, para orang tua berharap pembelajaran tatap muka bisa segera dilaksanakan untuk mengurangi kegiatan-kegiatan kurang positif dari para siswa.

Ada 5,7 \% orang tua siswa yang menyatakan setuju dengan syarat di sekolah memberikan aturan sesuai protokol kesehatan. Selanjutnya, ada 3,7 $\%$ yang menyatakan bahwa sudah 
saatnya kita melaksanakan adaptasi bari di era new normal. Sisanya, para orang tua menyatakan anaknya sudah rindu dengan sekolah (ada 3,3 \%), anak menjadi lebih terkondisikan $(0,8 \%)$ dan berserah diri kepada Allah Swt $(0,4 \%)$ karena berpendapat bahwa mencari ilmu itu wajib hukumnya.

Demikian alasan-alasan dari orang tua yang menyatakan setuju untuk dilaksanakan pembelajaran tatap muka. Secara umum, alasan dari orang tua siswa ini adalah agar pembelajaran lebih efektif dan maksimal, siswa sudah bosan dengan pembelajaran daring, orang tua bingung, dan agar anak menjadi lebih terkondisikan.

Berkenaan dengan alasan orang tua yang menyatakan tidak setuju untuk dilaksanakan pembelajaran tatap muka, ada $8,2 \%$ orang tua siswa yang menyatakan hal tersebut. Ada beberapa alasan mengenai hal ini yaitu sebagai berikut:

\section{Tabel 4 Alasan Menyatakan Tidak Setuju}

\begin{tabular}{clc}
\hline No & \multicolumn{1}{c}{ Alasan-alasan } & $\%$ \\
\hline 1 & Masih ada kasus & $55,6 \%$ \\
2 & $\begin{array}{l}\text { Ketaatan terhadap } \\
\text { protokol }\end{array}$ & $33,3 \%$ \\
3 & $\begin{array}{l}\text { Banyak klaster } \\
\text { pendidikan }\end{array}$ & $11,1 \%$ \\
\hline & Jumlah & $100 \%$ \\
\hline
\end{tabular}

Dari tabel tersebut, diketahui bahwa ada 55,6 \% menyatakan tidak setuju untuk dilaksanakan pembelajaran tatap muka langsung dikarenakan kondisi saat ini masih ada

${ }^{17}$ Ninis Chairunnisa, "Muncul Klaster Covid-19 Di Sekolah Tangsel, DPR: Jangan Sampai Di Wilayah Lain," Berita, Tempo.co, September 6, 2020, banyak kasus terkonfirmasi positif Covid-19, baik di daerah Kota Salatiga maupun secara nasional. Alasan ini sebagai bukti bahwa orang tua siswa khawatir anak-anaknya terkena virus ini.

Alasan berikutnya adalah karena orang tua berpendapat bahwa anakanak belum bisa sepenuhnya mentaati dan bertindak sesuai dengan protokol kesehatan. Orang tua khawatir ketika nanti di sekolah, siswa tidak bisa melaksanakan social distancing atau jaga jarak dengan teman-temannya, tidak sepenuhnya memakai masker, dan belum bisa sepenuhnya menjaga kebersihan diri dari lingkungan sekitar. Persentase orang tua yang mengkhawatirkan hal ini adalah sebanyak 33,3 \%.

Selain itu, ada juga orang tua yang khawatir dengan pelaksanaan pembelajaran tatap muka dikarenakan ada banyak bermunculan cluster Covid19 di dunia pendidikan. Ada banyak media cetak ataupun elektronik serta media sosial yang memberikan informasi tentang munculnya cluster pendidikan setelah dilaksanakan pembelajaran tatap muka. Misalnya di daerah Tangerang Selatan sebagaimana diberitakan di media Tempo.co. Di berita tersebut disampaikan bahwa ada sebanyak 15 guru dan pegawai sekolah di salah satu sekolah di Tangerang Selatan dilaporkan positif Covid-19.17 Persentasi alasan dari kekhawatiran tentang munculnya cluster pendidikan ini adalah sebesar $11,1 \%$.

Selanjutnya, orang tua siswa yang masih ragu-ragu antara memilih setuju atau tidak setuju untuk dilaksanakan

https://nasional.tempo.co/read/1383230/ muncul-klaster-covid-19-di-sekolah-tangseldpr-jangan-sampai-di-wilayah-

lain/full\&view=ok. 
pembelajaran tatap muka ini sejumlah $17,3 \%$ orang. Dari jumlah tersebut, ada beberapa alasan yang melatar belakanginya yaitu sebagai berikut:

Tabel 5 Alasan Menyatakan Ragu-ragu

\begin{tabular}{|c|c|c|}
\hline No & Alasan-alasan & $\%$ \\
\hline 1 & Masih ada kasus & $47,4 \%$ \\
\hline 2 & $\begin{array}{l}\text { Ketaatan } \\
\text { protokol }\end{array}$ & $45,6 \%$ \\
\hline 3 & $\begin{array}{l}\text { Belum faham sistem } \\
\text { PTM }\end{array}$ & $7,0 \%$ \\
\hline & Jumlah & $100 \%$ \\
\hline
\end{tabular}

Dari tabel tersebut, diketahui bahwa ada 47,4 \% memberikan alasan masih adanya kasus Covid-19 pada saat ini, bahkan ada kecenderungan banyak penambahan kasus setiap hari. Alasan berikutnya adalah sebanyak 45,6 \% yang memberikan alasan bahwa anakanak masih belum bisa sepenuhnya mentaati protokol kesehatan. Selanjutnya ada 7 \% yang menyatakan ragu-ragu karena belum memahami sistem protokol kesehatan yang dilakukan pada saat pembelajaran tatap muka ini. Alasan-alasan inilah yang membuat orang tua masih meragukan untuk dilaksanakan pembelajaran tatap muka.

Dari berbagai pemaparan di atas, ada beberapa hal penting yang perlu dibahas. Pertama, mengenai persepsi orang tua, mayoritas orang tua menghendaki kegiatan pembelajaran dilaksanakan secara langsung di sekolah dengan melaksanakan protokol kesehatan yang ketat. Protokol kesehatan menjadi penting untuk diperhatikan mengingat kondisi saat ini

18 R. Rr Hasri Sulistiyani, Ruly Darmawan, and Lies Neni Budiarti, "Fleksibilitas Ruang Kelas Sebagai Upaya Memenuhi Kebutuhan Dalam Membangun Motivasi Anak Di TK Bunda Ganesa dimana kasus terkonfirmasi positif terpapar Covid-19 masih selalu bertambah. Protokol kesehatan ini juga penting agar tidak terjadi cluster Covid19 di bidang pendidikan serta untuk menjaga dan memastikan kesehatan dari para peserta didik.

Kedua, perbedaan pendapat antara orang tua yang setuju dan yang tidak setuju dengan pembelajaran tatap muka pada penelitian didasarkan pada kesehatan fisik dan kesehatan mental bagi para peserta didik. Orang tua yang setuju dengan pembelajaran tatap muka berharap agar kejenuhan anak-anak selama pembelajaran jarak jauh bisa terselesaikan. Sedangkan orang tua yang tidak setuju dengan pembelajaran tatap muka lebih didasarkan atas kesehatan putra-putrinya dan menjauhkan diri dari Covid-19.

Memilih melaksanakan pembelajaran secara tatap muka merupakan pilihan dilematis bagi semua pihak, baik guru, orang tua, dan juga pemerintah selaku pengambil kebijakan. Apalagi banyak kasus baru penderita Covid-19 di berbagai instansi yang menunjukkan semakin luasnya penyebaran penyakit baru tersebut. Kesehatan anak-anak menjadi penting dan prioritas yang dalam teori Maslow disebutkan bahwa kebutuhan rasa aman dan keselamatan lebih penting dari kebutuhan kognitif ataupun kebutuhan aktualisasi diri.18 Namun, tidak melaksanakan pembelajaran secara tatap muka dengan tetap memilih pembelajaran jarak jauh ini menyisakan banyak permasalahan yang muncul. Permasalahan yang muncul ini beragam sumbernya, dari sumber daya manusia,

Bandung," Jurnal Sosioteknologi 13, no. 1 (April 1, 2014): 67, https://doi.org/10.5614/sostek. itbj.2014.13.1.7. 
ketersediaan teknologi informasi, dan bahkan soal ekonomi.

Secara lebih khusus, berkaitan dengan pembelajaran tahfizh Al-Qur'an yang menjadi program khusus dari lokasi penelitian ini adalah bahwa tidak semua orang tua bisa mendampingi putra-putrinya untuk mengikuti program menghafal Al-Qur'an secara jarak jauh. Agar diperoleh kualitas yang baik, peserta didik perlu bertatap muka langsung dengan gurunya untuk melakukan pembelajaran. Hal inilah yang juga menjadi alasan orang tua memilih setuju dengan pembelajaran tatap muka secara langsung di sekolah.

Pemerintah selaku pengambil kebijakan diharapkan mampu memberikan solusi tepat yang mempertimbangan banyak aspek kehidupan. Jika pemerintah mengambil kebijakan untuk dilaksanakan pembelajaran tatap muka, protokol kesehatan harus dilaksanakan secara ketat dan didukung oleh semua pihak. Jika pilihan yang diambil adalah tetap melaksanakan pembelajaran secara daring, maka pemerintah juga harus menyediakan sarana dan fasilitas yang memadai agar tidak menimbulkan problematika yang berkelanjutan tanpa ada solusi.

\section{SIMPULAN}

Hasil penelitian ini diperoleh data bahwa berkenaan dengan pembelajaran tatap muka, mayoritas orang tua menyatakan setuju (74,5 \%). Sedangkan sisanya menyatakan tidak setuju sebanyak 8,2 \% dan ragu-ragu sebanyak $17,3 \%$. Alasan yang menyatakan setuju adalah agar pembelajaran lebih efektif, pembelajaran daring kurang maksimal, anak-anak sudah bosan, orang tua sudah bingung, agar siswa menjadi semangat, ketika di rumah anak menjadi kurang baik, dilaksanakan asalkan dengan protokol kesehatan, saat ini sudah waktunya adaptasi, anak sudah merindukan sekolah, anak menjadi lebih terkondisikan, dan berserah diri kepada Allah Swt. Alasan menyatakan tidak setuju adalah untuk menjaga kesehatan putra-putrinya dimana saat ini masih ada kasus terkonfirmasi positif Covid-19, anak yang tidak bisa mentaati protokol kesehatan, dan bermunculan banyak klaster pendidikan. Alasan menyatakan raguragu adalah saat masih ada kasus, anakanak yang tidak bisa mentaati protokol kesehatan, dan orang tua belum faham sistem pembelajaran tatap muka.

\section{REFERENSI}

Arikunto, S., Prosedur Penelitian Suatu pendekatan Praktek. (Jakarta: Rineka Cipta, 2010), 173.

Bahri, Syamsul, and Novira Arafah. "Analisis Manajemen SDM Dalam Mengembangkan Strategi Pembelajaran Di Era New Normal." Tafkir: Interdisciplinary Journal of Islamic Education 1, no. 1 (August 11, 2020): 20-40.

Chairunnisa, Ninis. "Muncul Klaster Covid-19 Di Sekolah Tangsel, DPR: Jangan Sampai Di Wilayah Lain." Berita. Tempo.co, September 6, 2020.

https://nasional.tempo.co/read/ 1383230/muncul-klaster-Covid19-di-sekolah-tangsel-dprjangan-sampai-di-wilayahlain/full\&view=ok.

Creswell, J. W. Research Design: Qualitative Quantitative and Mixed Methods Approaches. (Thousand Oaks: SAGE Publications, Inc, 2014) 
Drever, J., Kamus Psikologi (The Penguin Dictionary of Psychology), N. Simanjuntak, Ed. (Jakarta: PT. Bina Aksara, 1988), 338.

Ivancevich, J. M., Konopaske, R., \& Matteson, M. T., Perilaku dan Manajemen Organisasi (Organizational Behavior and Management, Seventh Edition). (G. Gania, Ed.) (Jakarta: Erlangga, 2006), 116.

Kariem, Muhammad Qur'anul. "Konsepsi Kebijakan Pemerintah di Era New Normal." TheJournalish: Social and Government 1, no. 2 (June 26, 2020): 76-80.

Kreitner, R., \& Kinicki, A., Perilaku Organisasi (Organizational Behavior). (E. Suandy, Ed.) (Jakarta: PT. Salemba Empat, 2003), 208.

Luthan, F., Perilaku Organisasi (Organizational Behavior 10th Edition). (A. V. Yuono, S. Purwanti, T. Arie P, \& R. Winong, Eds.) (Yogyakarta: Penerbit Andi, 2006), 194-197

Moleong, L. J. Metodologi Penelitian Kualitatif. (Bandung: Remaja Rosdakarya, 2007)

Pangondian, Roman Andrianto, Paulus Insap Santosa, and Eko Nugroho. "Faktor-Faktor Yang Mempengaruhi Kesuksesan Pembelajaran Daring Dalam Revolusi Industri 4.0." Seminar Nasional Teknologi Komputer \&
Sains (SAINTEKS) 1, no. 1 (February 21, 2019). https://www.prosiding.seminarid.com/index.php/sainteks/articl e/view/122.

Sabiq, Ahmad Fikri. "Persepsi Orang Tua Siswa Tentang Kegiatan Belajar Di Rumah Sebagai Dampak Penyebaran Covid 19." CivicCulture: Jurnal Ilmu Pendidikan PKn Dan Sosial Budaya 4, no. 1 (2020): 01-07.

Setyorini, In. "Pandemi COVID-19 Dan Online Learning: Apakah Berpengaruh Terhadap Proses Pembelajaran Pada Kurikulum 13?" Journal of Industrial Engineering \& Management Research 1, no. 1 (July 5, 2020): 95-102.

https://doi.org/10.7777/jiemar.v 1i1.31.

Sugiyono, Metode Penelitian Kuantitatif, Kualitatif dan $R$ \& D. (Bandung: Alfabeta, 2012), 80.

Sulistiyani, R. Rr Hasri, Ruly Darmawan, and Lies Neni Budiarti. "Fleksibilitas Ruang Kelas Sebagai Upaya Memenuhi Kebutuhan Dalam Membangun Motivasi Anak Di TK Bunda Ganesa Bandung." Jurnal Sosioteknologi 13, no. 1 (April 1, 2014): 60-71. https://doi.org/10.5614/sostek.it bj.2014.13.1.7. 